\title{
Psychological Loneliness Among Arab Students At Irbid National University, Jordan
}

Khawla Al-Kadoumi, Irbid National Universities, Jordan Abdel Muhdi Sawalha, Irbid National Universities, Jordan Mr. Mohammad Al Momani, Irbid National Universities, Jordan

\begin{abstract}
The purpose of this study is to investigate the level of psychological loneliness among Arab students studying at Irbid National University, and to investigate the effect of year of study and gender of students on the level of psychological loneliness. The sample of the study consisted of 149 students, 133 males and 16 females from first, second, third and fourth years. Means and standard deviations and T-tests were used to analyze the results. The results show that there are statistically significant differences in psychological loneliness among Arab students studying at Irbid National University. The results indicate that there are statistically significant differences at $(\alpha=0.05)$ in the level of psychological loneliness among Arab students due to year of study variable but no statistically significant differences at $(\alpha=0.05)$ in psychological loneliness among Arab students due to gender variable.
\end{abstract}

Keywords: Psychological Loneliness among Arab Students

\section{INTRODUCTION}

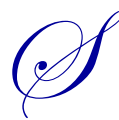

tudents have to cope with many problems while at university. According to prior research, university students have psychological, social, and sexual problems (Baysal \& Buluş, 2001; Gizir, 2005; Wechsler, Rohman, \& Solomon, 1991). In addition, they have problems with ego, identity development, and their relationships with others.

Students are worried about their future employment status (Şahin, Sezgin, Taş, \& Ruganc1, 1989). Students who must move to cities where there are universities are especially likely to suffer from loneliness in the new environment (Sawir, Marginson, Deumert, Nyland, \& Ramia, 2007). Loneliness is an unsatisfactory, subjective, and psychological state occurring as a result of inconsistency between the person's existing social relations and the relations s/he aspires to (Ponzetti, 1990). Loneliness is a feeling resulting from perceived social network of relations when it is smaller or less satisfactory than what s/he wishes to have (Peplau \& Perlman, 1979). Loneliness is positively related to feeling depressed, abandoned, empty, hopeless, isolated, self-enclosed, nonsociable, and dissatisfied (Russell, Peplau, \& Cutrona, 1980). Loneliness may be experienced emotionally as isolation from intimate relationships with family members or peers (Weiss, 1974). In several studies it has been found that socio demographic variables such as gender, age, and marital status are predictors for loneliness (Kim, 2001; Pinquart, 2003).

For Horney (1945), the fear of loneliness is one of the basic fears of people. An individual gives love and congeniality to people to defeat this fear. He looks for ways of exiting and escaping from this fact when he needs. Studies conducted on the topic verify that loneliness is a very common problem today (Rokach, \& Brock, 1997; Russell, Peplau, \& Cutrano, 1980; Storr, 1989). Page and Cole (1991) found that 10\% of the adult population had this problem of loneliness. 
Loneliness, far beyond personal destruction, can cause serious diseases which may end up depression at the end. The person, who cannot avoid the vicious circle he is trapped into, feels unhappy, isolated, and lonely (Ministre de Travaux publics et Services gouvernementaux Canada, 2006).

Loneliness appears in different forms. For example, Leonard (1979) and Kallıopuska (1986) classified loneliness as deep loneliness which comes with depression, social statue loneliness which is formed by sensing self estranged in society, sensual loneliness which is formed when the person cannot get a respond to his mental expectations even if he is in fine physical and environmental circumstances, and hidden loneliness in which the behaviors are apparently normal.

For Sadler (1978), loneliness emerges as a feeling of intensive sadness and emptiness along with the sharpened need of depending someone and manifests itself in five different ways, namely interpersonal loneliness, social loneliness, cultural shock, psychological loneliness, existential loneliness some personal characteristics of people who experience loneliness are explained in the literature as well. While Horowitz and French (1979) determined these properties as non-functionality, Jones, Hobbs and Hockenbury (1982) determined them as lack of social skills and interests, and zodaşık (1989) purposed them as pessimism, anxiety, lack of confidence, and introversion.

Loneliness is a universal emotional and psychological experience. Loneliness is also seen as a normal experience that leads individual to achieve deeper self-awareness, a time to be creative, and an opportunity to attain self-fulfilment and to explore meaning of life (Yalom, 2001; Borys S, \&Perlman D.1985) Loneliness is also a condition of human life, an experience of humanizing which enables the person to sustain, extend, and deepen his/her humanity (Moustakas, C. 1961). According to Weiss (Weiss R, 1993), loneliness is caused not by being alone but being without some definite needed relationship or set of relationships. Loneliness appears always to be a response to the absence of some particular relational provision, such as deficits in the relational provisions involved in social support (DiTommaso et al, 2003).

However, the experience of loneliness is likewise unpleasant and distressing. Loneliness may also lead to people to submerge themselves into dependency relations, following direction, imitation, being like others, and striving for power and status (Peplau, L. 1982; Rokach A, Brock H.1997) Reading, watching TV, using the internet, social activities, attending parties, drinking, and also using drugs do not only signal loneliness, but these also may be some adaptive or maladaptive coping strategies university students use to overcome this unpleasant and distressing experience - loneliness (Yeh, M.2002) Researchers have indicated that adolescents experience more loneliness than any other age groups (Jones, W. Carver, M.1991) Late adolescence and early adulthood (i.e., university age) are especially high risk for experiencing loneliness (Deniz, M. Hamarta, E. Ari, R. 2005; Ponzetti, J. 1990; Cutrona, C. 1982) University is a transition period from being an adolescent to being an adult. It is a period for university students to seek and fulfil their sense of individuality and, at the same time, to seek and build close and social relationships with others. For many university students, this may be the first time they live away from their parents. They may move from the emotional and social support of their families. They leave home as well as their hometown friends. The separation of university students from their homes for the first time may create feelings of doubt, confusion, and anxiety, which the close companionship of residential halls may not totally prevent (Weiss, R.1993) Once entering the university, they need to re-evaluate their past relationships with parents, teachers, friends, and girlfriend/boyfriend. They begin to learn how to deal with the attachment and separation processes of interpersonal situations in normal psychological growth and begin to create their own unique self-image. Lack of social and emotional support for university students, may lead to the experience of social and emotional loneliness (Cutrona, C. 1982)

For the most part, loneliness research has tended to focus on individual factors, that is, either on personality factors or lack of social contacts (DiTommaso et al .2003) However, if one accepts the premise that loneliness is expressive of an individual's relationship to the community, then it is conceivable that the ways social relations are organized within the community will result in cross-cultural variations in the way people experience loneliness. Cross-cultural and individual differences, including personality (Goswick, R. Jones, W. 1981) gender (Borys, S. Perlman, D. 1985; Clinton, M. Anderson, L. 1999) and religious engagement (Hood, R. et al 1996) also have been considered as relevant factors in the study of loneliness. 


\section{SIGNIFICANCE OF THE STUDY}

Friends are a common occurrence. Separation reduces the frequency of interaction, makes the satisfactions provided by a relationship less available, and may raise fears that the relationship will be weakened by absence. Such events as moving to a new community, going away from home to summer camp or to university, or spending extended periods in institutions such as hospitals or prisons all affect social relationships, in addition the requirements of work often impinge on social relations outside of work in the form of business trips, extended hours spent working overtime, or the necessity of moving as part of career advancement. Evidence that physical separation puts people at risk for loneliness is readily available: for example Weis (1973) has noted the difficulties experienced by wives forced to move by their husband's work. However, Rubenstein $\boldsymbol{e t}$ al. (1979) maintain that the loneliness passes quickly for most people who move to a new community.

\section{STATEMENT OF THE PROBLEM}

The most obvious determinant of loneliness among students is the level of a student's social relationships. Changes in social contacts have already been treated as a precipitating factor in loneliness. There are several indications that lonely people have fewer social contacts than do other people (see Jones, in press). For instance, lonely students have been found to date less, and report fewer social activities, and to spend more time alone; whilst lonely senior citizens have less frequent contacts with their friends (Perlrnan et al., 1978).

\section{PURPOSE OF THE STUDY}

The purpose of the study is to investigate the level of psychological loneliness among Arab students studying at Irbid National University in light of the year and gender variables.

\section{QUESTIONS OF THE STUDY}

1. Are there any statistically significant differences in psychological loneliness among Arab students studying at Irbid national university?

2. Are there any statistically significant differences in psychological loneliness among Arab students studying at Irbid national university due to year variable?

3. Are there any statistically significant differences in psychological loneliness among Arab students studying at Irbid national university due to gender variable?

\section{DEFINITION OF TERMS}

Loneliness can be viewed as a psychological state in which people consider their relationships to be limited or inadequate in terms of quantity or quality (Perlman \& Peplau, 1981). Arab students from many Arab countries such as Saudi Arabia, Kuwait, United Arab Emirates and are studying at Irbid National University. This study is limited to all Arab students who are studying at Irbid National University and to any other similar sample.

\section{LITERATURE REVIEW}

Many studies were carried out on loneliness, loneliness is found to be related with psychosocial difficulties (e.g., low self-esteem, low social competence, and poorer social interactions), mental health problems (e.g., anxiety, depression, suicidal behaviors) and with physical health issues (e.g., poorer immune and cardiovascular functioning, sleep deficiencies). Based on the findings of the studies, a typical lonely person has several characteristics such as negative feelings like desperation, depression, impatient boredom, and self-depreciation; negative attitudes about oneself, other people, and about the causes of events; and passive, selfabsorbed and ineffective social behavior (Heinrich \& Gullone, 2006).

In literature, various factors were examined for the purpose of determining loneliness. According to the research findings, there were no differences between the loneliness levels of university students in terms of their grade (Le Roux \& Connors, 2001). In addition, the findings that the level of loneliness does not differ with respect 
to gender (Neto \& Barros, 2003) but there are still other findings that the loneliness levels of male individuals are higher than that of female individuals (Karahan et.al. 2004). Moreover, relationships were found between loneliness and certain personality factors. A relationship was found between loneliness and neuroticism, and neuroticism was reported to be the predictor of loneliness (Neto \& Barros, 2003). Furthermore, studies show that cultural background also plays an important role in loneliness experience (Neto \& Barros, 2003). Consequently, loneliness, a significant multi-dimensional phenomenon, has significant outcomes for mental health (Heinrich \& Gullone, 2006).

Little research focuses on the distinction between emotional and social loneliness, despite the fact that social loneliness specifically indicates a lack of companionship and is related to the number of close friends. Emotional loneliness, in its turn, indicates a lack of intimacy with close friends and has nothing to do with the number of friendships (Havens, \& Gierveld, 2004). Qualter and Munn found that individuals can be socially isolated without feeling lonely, while other individuals feel lonely without being socially isolated. It is evident that objective and subjective feelings of isolation are not as clearly related.

The quantitative and qualitative aspects of social relationships are distinct. In other words, the lack of specificity in the concept of loneliness has been discussed, and more research is needed to distinguish the different aspects of loneliness throughout the process of aging (Hughes et al., 2004). In this study, the researcher focused specifically on perceived subjective emotional loneliness. Developing a close relationship implies self-disclosure as a first step in establishing a confidant relationship, which is scary because of the potential rejection factor. Generally it has been agreed upon that the subjective situation of loneliness entails negative consequences at the level of both physical and mental health (Ernst \& Cacioppo, 1999).

\section{DESIGN AND METHODOLOGY}

\section{Population of the study}

The population of the study consisted of:

All Arab students studying at Irbid National University enrolling in the first semester 2011/2012 whom they form (587)

\section{Sample of the study}

The sample of the study comprised of (149) Arab students who are studying at Irbid National University, 133 male and 16 female students and a questionnaire was distributed among them as shown in Table 1 .

Table 1

\begin{tabular}{|c|c|c|c|}
\hline & & Frequency & Percent \\
\hline \multirow{4}{*}{ Year } & 1 & 59 & 39.6 \\
\cline { 2 - 4 } & 2 & 43 & 28.9 \\
\cline { 2 - 4 } & 3 & 28 & 18.8 \\
\cline { 2 - 4 } & 4 & 19 & 12.8 \\
\hline \multirow{4}{*}{ Sex } & Male & 133 & 89.3 \\
\cline { 2 - 4 } & Female & 16 & 10.7 \\
\cline { 2 - 4 } & Total & 149 & 100.0 \\
\hline
\end{tabular}

\section{Instrument of the study}

A questionnaire was distributed among the students and this questionnaire was designed by the researchers. To ensure the questionnaire reliability, the researchers applied it to a pilot sample of (20) subjects excluded of the study sample in the same university from which the subjects were chosen with a two-week period between the first and second time it was distributed. The reliability of the test was calculated using correlation coefficient, it was found to be 79 and this is suitable to conduct such a study. This study was conducted over one semester period. This study was quantitative in nature. At the beginning of the study, a questionnaire about students' attitudes towards 
their feelings of loneliness was given to (149) students who are studying at Irbid National University. After that the researchers collected the questionnaires and collected data, and then this data was analyzed statistically. The results were analyzed for each item in the questionnaire using suitable statistical methods such as mean and standard deviation. The researchers also used figures to clarify the results more.

\section{Findings of the Study}

To answer the first question about the level of psychological loneliness: Are there any statistically significant differences in psychological loneliness among Arab students studying at Irbid national university? A questionnaire was distributed among them and means and standard deviation were calculated. Results were shown in Table 2 .

Table 2: level of psychological loneliness means and standard deviations

\begin{tabular}{|c|c|c|c|c|}
\hline Rank & No & Item & Mean & Std. Deviation \\
\hline 1 & 19 & Q19 & 3.19 & 1.018 \\
\hline 2 & 25 & Q25 & 3.14 & .923 \\
\hline 3 & 22 & Q22 & 3.08 & .962 \\
\hline 4 & 21 & Q21 & 3.00 & 1.084 \\
\hline 5 & 20 & Q20 & 2.74 & .807 \\
\hline 6 & 12 & Q12 & 2.68 & 1.092 \\
\hline 7 & 4 & $\mathrm{Q} 4$ & 2.65 & .846 \\
\hline 8 & 11 & Q11 & 2.58 & .931 \\
\hline 8 & 23 & Q23 & 2.58 & .938 \\
\hline 10 & 9 & Q9 & 2.54 & .912 \\
\hline 11 & 24 & Q24 & 2.53 & .941 \\
\hline 12 & 6 & Q6 & 2.39 & .836 \\
\hline 13 & 10 & Q10 & 2.35 & 1.059 \\
\hline 14 & 5 & Q5 & 2.34 & .859 \\
\hline 15 & 30 & Q30 & 2.28 & 1.034 \\
\hline 16 & 28 & Q28 & 2.23 & 1.009 \\
\hline 17 & 17 & Q17 & 2.15 & .933 \\
\hline 18 & 29 & Q29 & 2.06 & .799 \\
\hline 19 & 1 & Q1 & 2.02 & .881 \\
\hline 20 & 7 & Q7 & 1.97 & .809 \\
\hline 21 & 8 & $\mathrm{Q} 8$ & 1.93 & .827 \\
\hline 22 & 2 & Q2 & 1.89 & .755 \\
\hline 23 & 26 & Q26 & 1.86 & .885 \\
\hline 24 & 27 & Q27 & 1.78 & .853 \\
\hline 25 & 15 & Q15 & 1.67 & .784 \\
\hline 26 & 16 & Q16 & 1.52 & .731 \\
\hline 27 & 3 & Q3 & 1.50 & .741 \\
\hline 28 & 14 & Q14 & 1.48 & .768 \\
\hline 29 & 13 & Q13 & 1.46 & .793 \\
\hline \multirow[t]{2}{*}{30} & 18 & Q18 & 1.37 & .738 \\
\hline & & All items & 2.23 & .336 \\
\hline
\end{tabular}

Table 2 shows the level of psychological loneliness among Arab students studying at Irbid National University; means and standard deviations were calculated. 149 students answered the questionnaire and the highest mean was (3.19) for the $19^{\text {th }}$ question. The lowest mean was (1.37) for the $18^{\text {th }}$ question. Standard deviation for the $19^{\text {th }}$ was not statistically significant as it was higher than $(\alpha \leq 0,05)$. The total items standard deviation was $(0.336)$ which is not significant. Questions $10,12,19,21,28$ and 30 show a great statistically significant difference at the level $(\alpha \leq 0,05)$ when they were $(1.059,1.092,1.018,1.084,1.009$ and 1.034 respectively).

To answer the second question about psychological loneliness and year variable: Are there any statistically significant differences in psychological loneliness among Arab students learning at Irbid national university due to year variable? Means and standard deviations were computed and Table 3 shows the results. 
Table 3: Means, standard deviations and t-test according to year variable

\begin{tabular}{|l|c|c|c|}
\hline & N & Mean & Std. Deviation \\
\hline $\mathbf{1}$ & 59 & 2.31 & .347 \\
\hline $\mathbf{2}$ & 43 & 2.22 & .285 \\
\hline $\mathbf{3}$ & 28 & 2.14 & .368 \\
\hline $\mathbf{4}$ & 19 & 2.17 & .338 \\
\hline
\end{tabular}

Table 3 shows there are statistically significant differences due to year variable. It shows the results of the questionnaire which was distributed among (149) male and female students about the level of their psychological loneliness. Means and standard deviations were calculated and results show that first year students got a higher mean which was (2.31); this indicates that first year students have more psychological loneliness. Third and fourth year students got a little bet lower mean than first year which was (2.14, and 2.17).

Standard deviation for first year students was $(0.347)$ which is lower than $(\alpha \leq 0,05)$ so it means that it is statistically significant. Standard deviation for the third and fourth year students was nearly the same; it was $(0.368$, and 0.338 ) which is also statistically significant. So, there is statistically significant difference in the level of psychological loneliness due to year variable.

\begin{tabular}{|l|l|}
\hline 1 & 2.31 \\
\hline 2 & 2.22 \\
\hline 3 & 2.14 \\
\hline 4 & 2.17 \\
\hline
\end{tabular}

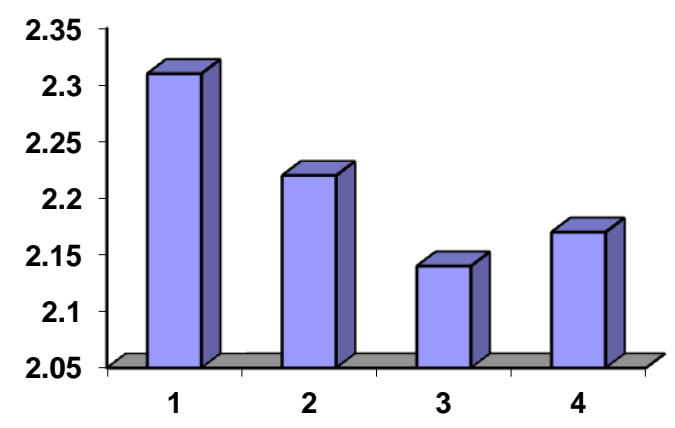

Diagram 1: T-Test (level of psychological loneliness due to year variable)

Diagram 1 show the level of psychological loneliness due to year variable, questionnaires was distributed among 149 Arab students and as it is clear here first year students have a higher mean than third and fourth students.

Table 3 shows a clear variance in the means of level of psychological loneliness according to year variable, to find out whether there are statistical significant differences in these means, one way ANOVA was conducted and the results are shown in Table 4.

Table 4: One way ANOVA results students related to year variable.

\begin{tabular}{|l|c|c|c|c|c|}
\hline & Sum of Squares & df & Mean Square & F & Sig. \\
\hline Between Groups & .651 & 3 & .217 & 1.954 & .124 \\
\hline Within Groups & 16.094 & 145 & .111 & & \\
\hline Total & 16.744 & 148 & & & \\
\hline
\end{tabular}

Table 4 shows there are no statistically significant differences at $(\alpha=0.05)$ in the level of psychological loneliness among Arab students due to year variable. 
To answer the third question about psychological loneliness and gender variable: Are there any statistically significant differences in psychological loneliness among Arab students learning at Irbid national university due to gender variable? Means and standard deviations were computed and Table 5 shows the results.

Table 5: Means, standard deviations and t-test according to gender variable

\begin{tabular}{|l|l|c|c|c|c|c|c|}
\hline & \multicolumn{1}{|c|}{ Sex } & $\mathbf{N}$ & Mean & Std. Deviation & t & df & Sig. (2-tailed) \\
\hline QALL & Male & 133 & 2.22 & .338 & -1.240 & 147 & .217 \\
\hline & Female & 16 & 2.33 & .314 & & & \\
\hline
\end{tabular}

Table 5 shows there are no statistically significant differences due to gender variable. It shows the results of the questionnaire which was distributed among (149) male and female students about the level of their psychological loneliness. Means and standard deviations were calculated and results show that male students got a nearly a similar mean as females which was (2.22, and 2.33) respectively; this indicates that first male students have the same psychological loneliness as female students.

Standard deviation for the male students was $(0.338)$ which is higher than $(\alpha \leq 0,05)$ so it means that it is not statistically significant. Standard deviation for the female students was nearly the same; it was (0.314) which is also not statistically significant. So, there is no statistically significant difference in the level of psychological loneliness due to gender variable.

Table 5 shows There are no statistically significant differences at $(\alpha=0.05)$ in psychological loneliness among Arab students due to gender variable.

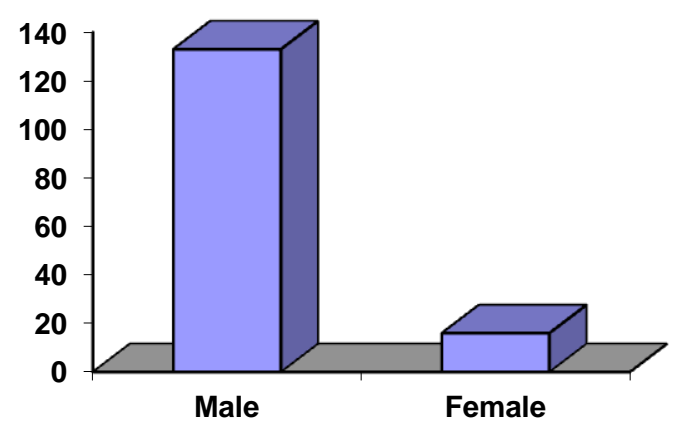

Diagram 2: T-Test (level of psychological loneliness due to gender variable)

Diagram 1 show the level of psychological loneliness due to gender variable, questionnaires was distributed among 149 Arab students and as it is clear here male students and female students have the same level of psychological loneliness.

\section{CONCLUSIONS}

Loneliness is a topic ripe for research. Studies have documented that loneliness is an unpleasant and widespread experience. The research literature on loneliness is relatively small (and thus easier to master) yet flourishing: and useful theoretical concepts and data collection instruments have been developed. Although the experimental manipulation of loneliness by researchers may be difficult and raises ethical issues, alternative research strategies have proved fruitful. Initial efforts to investigate loneliness empirically have been rewarded and available evidence suggests that psychologists are beginning to learn how to help people alleviate loneliness.

Yet despite these advances in the field, many important questions remain unanswered. All these factors make loneliness an attractive topic for research. Loneliness and depression are two main problematic areas for counseling-seekers, and there are gender and year-level differences for both. The research findings reveal the 
necessity to take gender and year-level into consideration in order to make effective interventions against the loneliness and depression problems of students applying university counseling centers.

\section{AUTHOR INFORMATION}

Dr. Khawla Al-Kadoumi, Assistant Prof in Educational psychology, Faculty of Educational Sciences, Irbid National University, 009627773000131,E-mail: kawla_qa@ hotmail.com

Dr. Abdel Muhdi Sawalha, Assistant Prof in Educational Counseling, Faculty of Educational Sciences, Irbid National University, 00962779636399, E-mail: $\underline{\text { abdalmuhdi@ hotmail.com }}$

Mr. Mohammad Al Momani, Master degree in Educational Counseling, 00962776574302, E-mail: dr_m8260@yahoo.com

\section{REFERENCES}

1. Borys S, Perlman D: Gender differences in loneliness. Personality and Social Psychology Bulletin 1985, 11:63-74.

2. Clinton M, Anderson L: Social and emotional loneliness: Gender differences and relationships with selfmonitoring and perceived control. Journal of Black Psychology 1999, 25:61-77.

3. Cutrona CE: Transition to college: Loneliness and the process of social adjustment. In Loneliness: A sourcebook of theory, research, and therapy. Edited by Peplau LA, Perlman D. New York: Wiley; 1982:291-309.

4. Deniz ME, Hamarta E, Ari R: An investigation of social skills and loneliness levels of university students with respect to their attachment styles in a sample of Turkish students. Social Behaviour and Personality 2005, 33:19-32.

5. DiTommaso, E., Brannan-McNulty, C., Ross, L., \& Burgess, M. (2003). Attachment styles, social skills and loneliness in young adults. Personality and Individual Differences, 35, 303-312.

6. Ernst, J., \& Cacioppo, J. (1999). Lonely hearts: Psychological perspectives on loneliness. Applied and Preventive Psychology, 8, 1-22.

7. Goswick R, Jones WH: Loneliness, self-concept and adjustment. The Journal of Psychology 1981, 107:237-240.

8. Heinrich, L. M., \& Gullone, E.(2006). The clinical significance of loneliness: A literature review. Clinical Psychology Review, 26, 695-718.

9. Hood R, Spilka B, Hunsberger B, Gorsuch R: The psychology of religion. New York: The Guilford Press; 1996

10. Horney, K. (1945). Our inner conflicts. New York: Norton.

11. Horowitz, L. M. \& French, R. S. (1979). Interpersonal problems of people who describe themselves as lonely. Journal of Consulting and Clinical Psychology, 47, 762-764.

12. Hughes, M. E., Waite, L. J., Hawkley, L. C. \& Cacioppo, J. T. (2004). A short scale for measuring loneliness in large surveys. Results from two population-based studies. Research on Aging, 26, 655-672.

13. Jones, W. H., Hobbs, S. A., \& Hockenbury, D. (1982). Loneliness and social skill deficits. Journal of Personality and Social Psychology, 42, 682-689.

14. Jones, W. H., Carver, M. D. (1991). Adjustment and coping implications of loneliness, R. Snyder \& D. R. Forsyth (Eds.), Handbook of social and clinical psychology: The healthy perspective (395-415) New York: Pergamon Press.

15. Kallopuska, M. (1986). Emphaty and the experiencing of loneliness. Psychological Reports, 59, 10521054.

16. Karahan, T.F., Sardoğan, M.E., Şar, A.H., Ersanlı, E., Kaya, S.N., \& Kumcağız, H. (2004). Üniversite Öğrencilerinin Yalnızlık Düzeyleri ile Benlik Saygısı Düzeyleri Arasındaki İlişkiler [The relationships between the levels of loneliness and levels of self-esteem of university students]. Ondokuz Mayls Üniversitesi Ë̆itim Fakültesi Dergisi, 18, 27-39.

17. Kim, O. (2001). Sex differences in social support, loneliness, and depression among Korean college students. Psychological Reports, 88, 521-526. 
18. Leonard, M. H. (1979). Interpersonal problems of people who describe themselves as lonely. Journal of Consulting and Clinical Psychology, 47 (4), 762-764.

19. Le Roux, A., \& Connors, J. (2001). A cross-cultural study into loneliness amongst university students. Journal of Psychology, 31(2), 46-52.

20. Ministre de Travaux publics et Services gouvernementaux Canada. (2006). Gouvernement du Canada, Le rapport Aspect humain de la santé mentale et de la maladie mentale au Canada, 2006. No de cat. HP519/2006F. Retrieved feb 14, 2012, from www.phac-aspc.gc.ca/ publicat/human-humain06/pdf/human face f. pdf

21. Moustakas CE: Loneliness. New Jersey: Prentice-Hall; 1961.

22. Neto, F., \& Barros, J.(2003). Predictors of loneliness among students and nuns in Angola and Portugal. The Journal of Psychology, 137(4), 351-362.

23. Page, R. M. \& Cole, G. E. (1991). Demographic predictors of self-reported loneliness in adults. Psychological Reports, 68, 939-945.

24. Peplau LA: Loneliness: A Sourcebook of Current Theory, Research and Therapy. John Wiley \& Sons Australia, Limited; 1982.

25. Peplau, L. A., \& Perlman, D. (1982). Loneliness: A sourcebook of current theory, research and therapy. New York: Wiley-Interscience.

26. Pinquart, M. (2003). Loneliness in married, widowed, divorced, and never-married older adults. Journal of Social and Personal Relationships, 20, 31-53.

27. Ponzetti, J. J. (1990). Loneliness among college students. Family Relations, 39, 336-340.

28. Rokach, A., \& Brock, H. (1997). Loneliness: A multidimensional experience. Psychology: A Journal of Human Behavior, 34, 1-9.

29. Russell, D., Peplau, L. A., \& Cutrona, C. E. (1980). The revised UCLA Loneliness Scale: Concurrent and discriminant validity evidence. Journal of Personality and Social Psychology, 39,472-480.

30. Şahin, N. H., Sezgin, N., Taş, Y., \& Ruganc1, N. (1989). Bilkent -niversitesi ğrencilerinin Danışma Rehberlik Araştırma Merkezi’nden Beklentileri -niversite Gençliğinde Uyum Sorunları Sempozyumu Bilimsel lalışmaları [Expectations of University of Bilkent students from the counselling service symposium for scientific study of adaptation problems of students]. Ankara Bilkent Üniversitesi (pp. 99120).

31. Sadler, W. (1978). Dimensions in the Problem of Loneliness: a Phenomenological Approach in Social Psychology. Journal of Phenomenological Psychology, 9 (1), 157-187.

32. Weiss RS: Loneliness: The experience of emotional and social isolation. London: MIT Press; 1973.

33. Weiss, R. S. (1974). The provision of social relationships. In Z. Rubin (Ed.), Doing unto others (pp. 17-26). Prentice-Hall.

34. Yalom I: Varoluscu Psikoterapi. İstanbul: Kabalc1 Pub; 2001.

35. Yeh MC: Loneliness, Alcohol and Marihuana Use among Male College Students. University of Connecticut; 2002. 


\section{NOTES}

